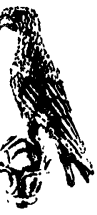

\title{
5TH INTERNATIONAL SYMPOSIUM ON APPLIED BIOINORGANIC CHEMISTRY
}

\author{
CORFU, GREECE, April 13 - 17 , 1999
}

\author{
Scope \\ Webb of Murdoch University, Perth, Australia. \\ 1) Metalloenzymes \\ 2) Biomaterials \\ 3) Metal Based Drugs \\ 4) Metals in the Environment and Metal Toxicology \\ 5) Bioelectronics \\ 6) Spectroscopic Applications \\ 7) Model Compounds \\ 8) Metal Speciation
}

The 5th International Symposium on Applied Bioinorganic Chemistry, 5th ISABC, is the 5th in a series of similar symposia that were first initiated by Kui Wang of Beijing Medical University and John

Though the field of Bioinorganic Chemistry has progressed considerably over the past years, the significance of its applications to human welfare and development have not yet been widely appreciated. Besides the International Conference of Bioinorganic Chemistry and the European Conference of Bioinorganic Chemistry, each one held every two years, the International Symposia on Applied Bioinorganic Chemistry were initiated to provide current perspectives on the science, besides the established applications of Bioinorganic Chemistry and to stimulate developments that would lead to further applications. It aims therefore to fill up the gap and emphasize mainly the possible applications of Bioinorganic Chemistry. With this purpose, the 5th International Symposium on Applied Bioinorganic Chemistry will involve Plenary and Session Lectures in the following topics:

Many experts of international reputation have accepted to take part to the 5th ISABC. Consequently, the participation of young scientists is strongly encouraged, so that they become aware of all possible modern applications of the field and in their turn contribute to its further development.

Venue and accommodation

The 5th ISABC will be held in the beautiful island of Corfu, located in the Northwest of Greece, approximately 1.5 hours by boat from the closest continental port of Igoumenitsa. The period of the Symposium, $13-17$ April, follows the Greek Easter Sunday (April 11, 1999) and may be of interest for those wishing to come a little earlier on this occasion. The average temperature in April in Corfu is expected to be about $20^{\circ} \mathrm{C}$.

In addition, Satellite Symposia on recent developments in Thalassemia (I) and modern NMR \& EPR spectroscopic applications (II) will be organized at the University of loannina, on 19 \& 20 of April, 1999. Ioannina is a town of approximately 120000 inhabitants, located $92 \mathrm{Km}$ west of the port of Igoumenitsa (the closest to Corfou).

The symposium will be held at the hotel CHANDRIS in Corfu and the official language will be English. Aproximate fare for half board pension per day, will be:

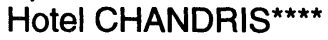

Half board, single room: 65 US $\$$

Half board, double room: 50 US $\$$ 
Other convenient and comfortable hotels located at the seashore at a walking distance from lecture halls will also be available. Details and information on hotel accomodation, air and sea connections will be given in the second circular.

\section{Submission of Abstracts for Contributed Papers}

Papers related to the general field of applied Bioinorganic Chemistry are welcome.

Abstract forms and instructions will be given in the Second Circular.

Registration fees will be 220 US $\$$ for active participants and 50 US $\$$ for accompanying persons. To encourage attendance by young scientists, registration fees will be reduced to only 75 US $\$$ for graduate students presenting oral papers or posters.

Additional 80 US $\$$ registration fees will be required for the attendance of the Satellite Symposia from active participants and will be free for graduate students.

The 5th ISABC is organized by the University of loannina Chairman: Prof. Nick HADJILIADIS

\section{International Organizing Committee}

-I. BERTINI (Italy) •I.S. BUTLER (Canada) • J. BUFFLE (Switzerland) • S.BERNS-PRICE (Australia) • D. COUCOUVANIS (USA) •I. GEROTHANASSIS (Greece) • M. GIELEN (Belgium)

$\bullet$ F. GONZALES-VILCHEZ (Spain) • G.E. JACKSON (South Africa) • L. N. JI (China) • N. KATSAROS $($ Greece) • V.G. KUMAR DAS (Malaysia) • E. KIMURA (Japan) • B. LIPPERT (Germany) • G. NATILE (Italy) • E. RATILA (Philippines) - J. REEDIJK (The Netherlands) $\bullet H$. SIGEL (Switzerland) - AG. SYKES (UK) • J.P. TUCHAGUE (France) $\bullet$ K. WANG (China) • J. WEBB (Australia) • D.R. WILLIAMS (UK)

\section{Local Organizing Committee}

- Nick HADJILIADIS, Univ. of loannina (Chairman)

- Nick KATSAROS, NCSR "DEMOKRITOS" Athens (Vice Chairman) • Spyros PERLEPES, Univ. of Patras - Dimitris KESSISSOGLOU, Univ. of Thessaloniki - Athanassios COUTSOLELOS, Univ. of Crete $\bullet$ Costas METHENITIS, Univ. of Athens - Theophile THEOPHANIDES, N.T. Univ. of Athens • Ioannis GEROTHANASSIS, Univ. of Ioannina $\bullet$ John TSANGARIS, Univ. of loannina • Themistoklis KABANOS, Univ. of Ioannina - Dimitra KOVALA-DEMERTZI, Univ. of Ioannina - John PLAKATOURAS, Univ. of Ioannina - Maria LOULOUDI, Univ. of loannina • Sotiris HADJIKAKOU, Univ. of loannina

Invited Speakers (will include):

-S.LIPPARD (USA) - J.REEDIJK (The Netherlands) • I.BERTINI (Italy) • D. WILLIAMS (UK) • V. PECORRARO (USA) • D. COUCOUVANIS (USA) • V. PAVONE (Italy) • B. SARKAR (Canada) • N. HADJILIADIS (Greece) • M. STILLMAN (Canada) • H. SIGEL (Switzerland) • E.KIMURA (Japan) • K. TIMMIS (Germany) • D. MANSUY (France) • K. KASPRZAK (USA) • K. WANG (China) $\bullet$ L. CASELLA (Italy) • G. SYKES (UK) • T. KISS (Hungary) • B. LIPPERT (Germany) • T. THEOPHANIDES (Greece) • G.E. JACKSON (S. Africa) • P. SADLER (UK) • I.S. BUTLER (Canada) • R. BARBUCCI (Italy) • J. WEBB (AUSTRALIA) • M.GIELEN (Belgium) • I. GEROTHANASSIS (Greece) •I. SOVAGO (Hungary) - F. GONZALES-VILCHEZ (Spain) - D. KESSISSOGLOU, (Greece) - G. NATILE (Italy) - H. KOZLOWSKI (Poland) • J.P. TUCHAGUE (France) • L.N. JI. (China)

Possible Participation of J.M. LEHN (France, Nobel Prize)

Conference secretariat

a) Dr.MariaLOULOUDI •Tel.: +30 65198418 or 98429 • Fax: +30 $65144831 \cdot$ e-mail: mlouloud@ cc.uoi.gr

b) Dr. Sotiris HADJIKAKOU • Tel.: +30 65198374 Fax: +30 $65144825 \cdot e-m a i l:$ shadjika @ cc.uoi.gr

5th ISABC Secretariat

University of loannina, Department of Chemistry, Laboratory of Inorganic \& General Chemistry

GR-451 10, loannina, Greece 